\title{
Impact of restriction of the Atlantic-Mediterranean gateway on the Mediterranean Outflow Water and eastern Atlantic circulation during the Messinian
}

\author{
J. N. Pérez-Asensio, ${ }^{1}$ J. Aguirre, ${ }^{1}$ G. Schmiedl, ${ }^{2}$ and J. Civis ${ }^{3}$ \\ Received 1 March 2012; revised 16 July 2012; accepted 17 July 2012; published 28 August 2012.
}

[1] Messinian foraminiferal stable oxygen and carbon isotopes of the Montemayor-1 core (Guadalquivir Basin, SW Spain) have been investigated. This record is exceptional to study the Mediterranean Outflow Water (MOW) impact on the Atlantic meridional overturning circulation (AMOC) and global climate during the Messinian because the core is near the Guadalhorce Corridor, the last Betic gateway to be closed during the early Messinian. Our results allow dating accurately its closure at $6.18 \mathrm{Ma}$. Constant benthic $\delta^{18} \mathrm{O}$ values, high difference between benthic and planktonic $\delta^{18} \mathrm{O}$, and low sedimentation rates before $6.18 \mathrm{Ma}$ indicate the presence of a two-layer water column, with bottom winnowing due to an enhanced Mediterranean outflow current. The enhanced contribution of dense MOW to the North Atlantic Ocean likely fostered the formation of North Atlantic Deep Water (NADW). After $6.18 \mathrm{Ma}$, benthic $\delta^{18} \mathrm{O}$ values parallel that of the global glacioeustatic curve, the difference between benthic and planktonic $\delta^{18} \mathrm{O}$ is low, and sedimentation rates considerably increased. This indicates a good vertical mixing of the water column, interruption of the MOW, and a dominant glacioeustatic control on the isotopic signatures. According to the role of MOW in the modern Atlantic thermohaline circulation, the reduction of the MOW after the closure of the Guadalhorce Corridor might have resulted in a decreased NADW formation rate between 6.0 and $5.5 \mathrm{Ma}$ weakening the AMOC and promoting northern hemisphere cooling. After the Gibraltar Strait opening, the restoration of the MOW and related salt export from the Mediterranean could have promoted an enhanced NADW formation.

Citation: Pérez-Asensio, J. N., J. Aguirre, G. Schmiedl, and J. Civis (2012), Impact of restriction of the Atlantic-Mediterranean gateway on the Mediterranean Outflow Water and eastern Atlantic circulation during the Messinian, Paleoceanography, 27, PA3222, doi:10.1029/2012PA002309.

\section{Introduction}

[2] At present, the Mediterranean connects with the Atlantic by the Strait of Gibraltar. The water mass exchange throughout the Strait of Gibraltar is characterized by an antiestuarine circulation pattern (Figure 1a) [Wüst, 1961]. This anti-estuarine circulation pattern was definitively established after the opening of the Strait of Gibraltar [Nelson, 1990], although it has been suggested that the movements of water masses reversed to estuarine-type circulation during the

\footnotetext{
${ }^{1}$ Departamento de Estratigrafía y Paleontología, Facultad de Ciencias, Universidad de Granada, Granada, Spain.

${ }^{2}$ Department of Geosciences, University of Hamburg, Hamburg, Germany.

${ }^{3}$ Departamento de Geología, Universidad de Salamanca, Salamanca, Spain.

Corresponding author: J. N. Pérez-Asensio, Departamento de Estratigrafia y Paleontología, Facultad de Ciencias, Universidad de Granada, Avenida Fuentenueva s.n., ES-18002 Granada, Spain. (jnoel@ugr.es)

C 2012. American Geophysical Union. All Rights Reserved. 0883-8305/12/2012PA002309
}

early Pleistocene [Huang and Stanley, 1972]. Lower salinity surface waters from the North Atlantic flow superficially eastward into the Mediterranean (Figure 1a). On the other hand, strong evaporation and production of dense, saline intermediate and deep waters in the eastern Mediterranean forces a high-velocity density driven bottom current westward as MOW through the Strait of Gibraltar. This mass of water is mainly fed by the Levantine Intermediate Water (LIW) [Bryden and Stommel, 1984], formed by convection in the Eastern Mediterranean [Marshall and Schott, 1999; Hernández-Molina et al., 2011], and in lesser extent by the Western Mediterranean Deep Water (WMDW), which is formed in the Gulf of Lion during cold and windy winters [MEDOC Group, 1970; Bryden and Stommel, 1984; Lacombe et al., 1985]. Today, the LIW contributes to $2 / 3$ of the MOW while WMDW only represents $1 / 3$ of the MOW [Millot, 1999]. Therefore, the LIW might be more important in controlling the MOW than WMDW. The MOW is characterized by higher $\delta^{13} \mathrm{C}$ and $\delta^{18} \mathrm{O}$ than the Atlantic waters [VergnaudGrazzini, 1983; Sierro et al., 2005].

[3] The outflow of the MOW into the Eastern Atlantic has a significant effect on the Atlantic oceanic circulation as well 
a)
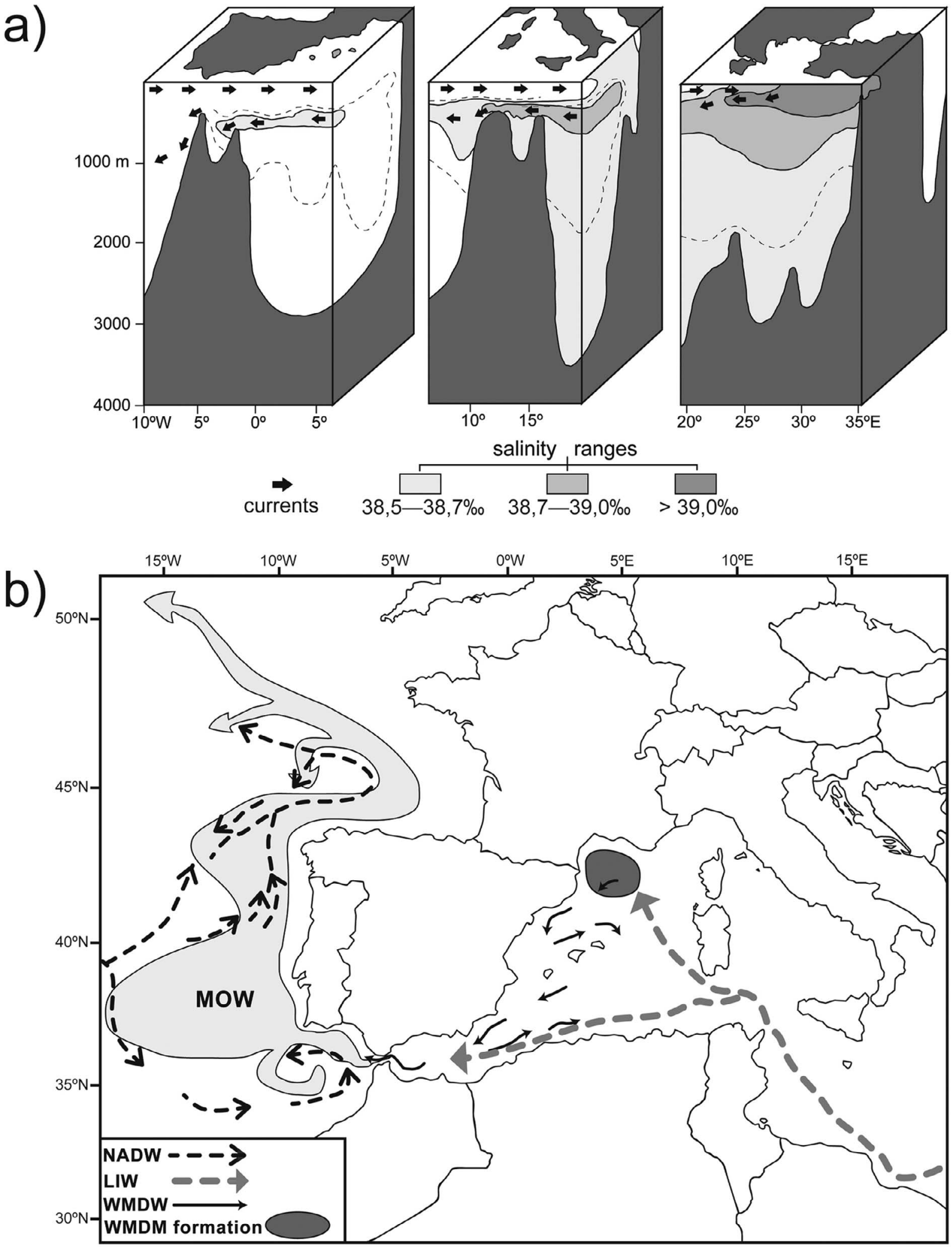

Figure 1. (a) Present salinity and circulation patterns at the Strait of Gibraltar and in the Mediterranean (based on Wüst [1961]). The dense and saline Mediterranean intermediate and deep waters form a bottom outflow, while lower salinity surface waters from the Atlantic enters the Mediterranean representing an anti-estuarine circulation pattern. (b) Present-day general circulation pattern at the eastern North Atlantic and Mediterranean Sea (based on Hernández-Molina et al. [2011] and Pinardi and Masetti [2000]). Mediterranean Outflow Water (MOW), North Atlantic Deep Water (NADW), Levantine Intermediate Water (LIW), Western Mediterranean Deep Water (WMDW) and WMDW formation are indicated. 
as on the global climate. The dense MOW mixes with the North Atlantic intermediate waters forming a high salinity tongue (Figure $1 \mathrm{~b}$ ) that contributes to the momentum of the Atlantic meridional overturning circulation (AMOC) $[$ Reid, 1979; Rahmstorf, 1998; Bigg and Wadley, 2001; Bigg et al., 2003]. In turn, the $\mathrm{AMOC}$ is the driving force for the Atlantic Ocean circulation, and even the global thermohaline circulation [Bethoux et al., 1999]. Global thermohaline circulation affects the global radiation budget and global carbon cycling and can thus produce major climate changes [Brown et al., 1989; Bigg et al., 2003; Murphy et al., 2009]. Therefore, a reduction or interruption of the MOW could have a critical impact both on the AMOC and on the global circulation, as well as on the global climate. Without the contribution of the saline MOW, the formation of dense water, which triggers the AMOC, would have most likely not taken place steadily in the North Atlantic [Rahmstorf, 1998; Bethoux et al., 1999].

[4] The impact of the MOW on the Atlantic Ocean circulation during the Pliocene, Pleistocene, and Holocene, has been comprehensively studied [Loubere, 1987; Nelson et al., 1993; Schönfeld, 1997; Maldonado and Nelson, 1999; Schönfeld and Zahn, 2000; Rogerson et al., 2005; Hernández-Molina et al., 2006, 2011; Llave et al., 2006, 2011; Toucanne et al., 2007; Khélifi et al., 2009; Rogerson et al., 2010, 2011, 2012; Stumpf et al., 2010; Van Rooij et al., 2010; Estrada et al., 2011]. These studies show an Upper North Atlantic Deep Water (UNADW) formation produced by an enhanced MOW flow related to an increased Mediterranean deep-water formation and enhanced aridity in the Mediterranean region. Furthermore, the supply of salt by the MOW into the intermediate North Atlantic waters favors the resumption of the AMOC during interglacials [Rogerson et al., 2006, 2012; Voelker et al., 2006].

[5] All these studies have analyzed the history and impact of the MOW on the Atlantic circulation after the end of Messinian salinity crisis (MSC), when the Atlantic-Mediterranean connections were reestablished through the Strait of Gibraltar. However, little is known about the impact of the MOW during the Messinian, when the connections were through the Betic and Rifian Corridors [van der Laan et al., 2012] or after the cessation of the MOW due to the closure of these corridors. Keigwin et al. [1987] questioned that the MSC had any effect on the deep circulation in the North Atlantic. On the contrary, Zhang and Scott [1996] reported the presence of the MOW at the northeastern Atlantic Ocean, at least reaching $50^{\circ} \mathrm{N}$ of latitude, during the Messinian. Moreover, $\mathrm{Pb}$ and $\mathrm{Nd}$ isotopic studies also pointed out to the influence of the MOW in the NE Atlantic during the Messinian [Abouchami et al., 1999]. Apart from these works deciphering the influence of the MOW in the distant Atlantic, no study has focused on the areas close to the Atlantic-Mediterranean connections in the Betics.

[6] It has been largely substantiated that the restriction of the Atlantic-Mediterranean connections played a major role in the onset of the MSC [e.g., Esteban et al., 1996; Riding et al., 1998; Krijgsman et al., 1999a, 1999b; Martín et al., 2001; Braga et al., 2006]. The Betic Corridors together with their southern counterparts, the Rifian Corridors (NW Morocco), were the main gateways connecting the Atlantic and Mediterranean until their closure [Benson et al., 1991;
Esteban et al., 1996; Martín et al., 2001, 2009; Betzler et al., 2006].

[7] The Guadalquivir Basin, located in the south of the Iberian Peninsula, represents the Atlantic side of the Betic Corridors that extended through southern Spain during the early late Miocene [Benson et al., 1991; Martín et al., 2001, 2009; Braga et al., 2002]. The last active Betic gateway was the Guadalhorce Corridor, which controlled the Messinian pre-evaporitic circulation in the western Mediterranean, and allowed the MOW to enter the Atlantic Ocean [Martín et al., 2001]. The Guadalhorce Corridor was a NW-SE trending strait with an estimated maximum width of $5 \mathrm{~km}$ and maximum water depth of $120 \mathrm{~m}$ [Martin et al., 2001]. The corridor was filled by sediment displaying huge unidirectional sedimentary structures indicating Mediterranean waters flowing out into the Atlantic at estimated current velocities of about 1.0-1.5 m/s [Martín et al., 2001]. This water mass circulation is consistent with the siphon model of Benson et al. [1991] stating that prior to the closure of the Betic Corridors, the water exchange between the Mediterranean and the Atlantic during the Messinian was characterized by Atlantic inflow through the Rifian Corridors and MOW through the Guadalhorce Corridor [Benson et al., 1991; Martín et al., 2001]. After the closure of the Guadalhorce Corridor in the early Messinian [Martín et al., 2001], MOW was interrupted and circulation was restricted to the Rifian Corridors [Esteban et al., 1996]. Later the closure of the Rifian Corridors in the late Messinian [Krijgsman et al., 1999a] caused the isolation of the Mediterranean Sea and, consequently, a hydrographical deficit that triggered the onset of the MSC with deposition of extensive evaporites in the central and deeper parts of the Mediterranean [Hsü et al., 1973, 1977].

[8] In this study, we examine the impact of the MOW during the Messinian close to the Betic corridors. We analyze foraminiferal stable $\mathrm{O}$ and $\mathrm{C}$ isotope composition in the Montemayor-1 core (SW Spain) (Figure 2). The core site is located close to the Guadalhorce Corridor, the last Betic corridor to be closed [Martín et al., 2001, 2009], and shows a continuous Messinian record accurately dated by magnetobiostratigraphic methods [Larrasoaña et al., 2008]. The Guadalquivir Basin was well connected with the Atlantic Ocean during the MSC, so there was neither desiccation nor evaporite deposition. Furthermore, according to the siphon model of Benson et al. [1991], Mediterranean outflow took place only throughout the Betic Corridors. Therefore, the location of the core is exceptional to study the effect of the MOW on the eastern Atlantic Ocean circulation during the Messinian, as well as its possible impact on global climate changes.

[9] The main aims of this study are: 1) to assess the impact of the MOW on the AMOC during the Messinian; and 2) to precisely date the closure of the Guadalhorce Corridor.

\section{Geological Setting}

[10] The study area is located in the westernmost part of the northwestern edge of the lower Guadalquivir Basin (SW Spain) (Figure 2). This is an ENE-WSW elongated Atlantic Neogene foreland basin [Sanz de Galdeano and Vera, 1992; Vera, 2000; Braga et al., 2002] with a sedimentary infilling 


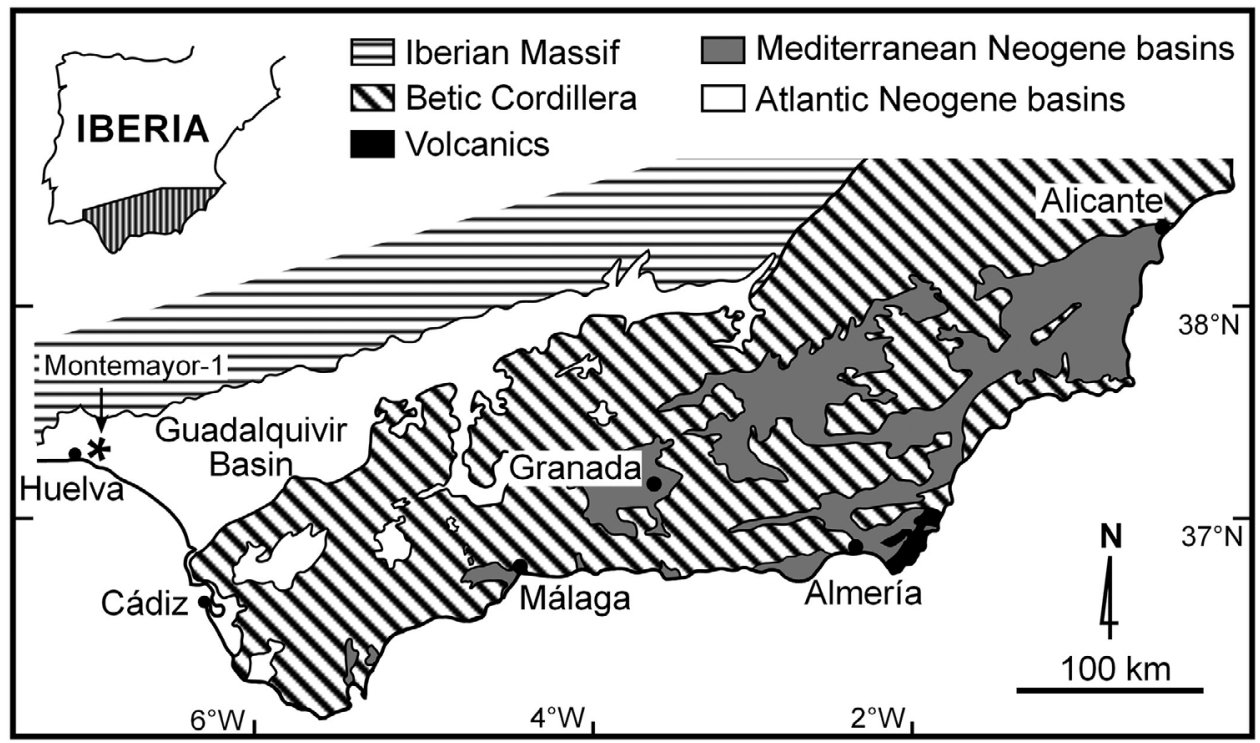

Figure 2. Geological setting of the lower Guadalquivir Basin. Asterisk indicates the location of the Montemayor-1 core.

consisting of marine and continental sediments ranging from the early Tortonian to the late Pliocene [Aguirre, 1992, 1995; Aguirre et al., 1993, 1995; Riaza and Martínez del Olmo, 1996; Sierro et al., 1996; Braga et al., 2002; González-Delgado et al., 2004; Martín et al., 2009].

[11] The Guadalquivir foreland basin was formed as a consequence of the Betic Cordillera compressional overthrusting during the early middle Miocene [Sanz de Galdeano and Vera, 1992; Riaza and Martínez del Olmo, 1996; Sanz de Galdeano and Rodríguez-Fernández, 1996; Martín et al., 2009; Braga et al., 2010]. During the Serravallian, the Atlantic-Mediterranean connection started to be restricted in the northeastern edge of the Guadalquivir Basin, in the Prebetic Domain of the Betic Cordillera [Aguirre et al., 2007; Martín et al., 2009; Braga et al., 2010]. The progressive tectonic uplifting of the Betic mountain chain led to a progressive closure of this seaway, originating the so-called North Betic Strait during the latest middle Miocene-earliest late Miocene (topmost Serravallian-earliest Tortonian) [Aguirre et al., 2007; Martin et al., 2009; Braga et al., 2010]. The final closure of the North Betic Strait took place during the early Tortonian [Sierro et al., 1996; Martín et al., 2009; Braga et al., 2010] and the Guadalquivir Basin was established as a wide, marine embayment only opened to the Atlantic Ocean [Martin et al., 2009].

[12] After the cessation of the North Betic Strait, other Betic gateways connected the Atlantic and the Mediterranean through the Guadalquivir Basin. They were progressively closed during the late Miocene. In the late Tortonian, the Dehesas de Guadix Corridor and the Granada Basin were the main Atlantic-Mediterranean connections [Esteban et al., 1996; Braga et al., 2003; Betzler et al., 2006; Martín et al., 2009]. After their closure, the Guadalhorce Corridor was the only connection during the earliest Messinian [Martín et al., 2001]. This last Betic Corridor became closed in the early Messinian [Martín et al., 2001]. Since its closure, the
Rifian Corridors were the unique Atlantic-Mediterranean gateways [Esteban et al., 1996].

\section{Material and Methods}

\subsection{Montemayor-1 Core}

[13] The studied material is the Montemayor-1 core, a $260 \mathrm{~m}$ long core that has been drilled in the northwestern margin of the lower Guadalquivir Basin close to Moguer (SW Spain) (Figures 2 and 3). This core includes marine sediments that can be divided into four lithostratigraphic units [see a detail description in Pérez-Asensio et al., 2012] (Figure 3): the Niebla Formation (Tortonian), the Arcillas de Gibraleón Formation (latest Tortonian-Messinian), the Arenas de Huelva Formation (early Pliocene), and the Arenas de Bonares Formation (late Pliocene-Pleistocene).

[14] In this study, we analyzed an interval of $70 \mathrm{~m}$, from 240 to $170 \mathrm{~m}$ (from 6.67 Ma to $5.7 \mathrm{Ma}$ according to the age model. See below), including Messinian sediments from the Arcillas de Gibraleón Formation (Figure 3). In this interval, a total of 132 samples were collected with a sampling interval of $0.5 \mathrm{~m}$. Samples were wet sieved over a $63 \mu \mathrm{m}$ mesh and dried out in an oven at $40^{\circ} \mathrm{C}$. A representative split was dry-sieved over a $125 \mu \mathrm{m}$ mesh to estimate the planktonic/benthic ratio ( $\mathrm{P} / \mathrm{B}$ ratio henceforth), calculated as $[\mathrm{P} /(\mathrm{P}+\mathrm{B})]$ as a proxy for relative sea level change.

\subsection{Stable Isotope Analyses}

[15] Stable isotope analyses $\left(\delta^{18} \mathrm{O}\right.$ and $\left.\delta^{13} \mathrm{C}\right)$ were performed on 10 individuals of Cibicidoides pachydermus for benthic foraminifera and 20 individuals of Globigerina bulloides for planktonic foraminifera separated from the size fraction $>125 \mu \mathrm{m}$. Foraminiferal shells were ultrasonically cleaned, and washed with distilled water prior to the analyses. The isotopic analyses were performed on a Finnigan MAT 251 mass spectrometer connected to a Kiel I (prototype) 


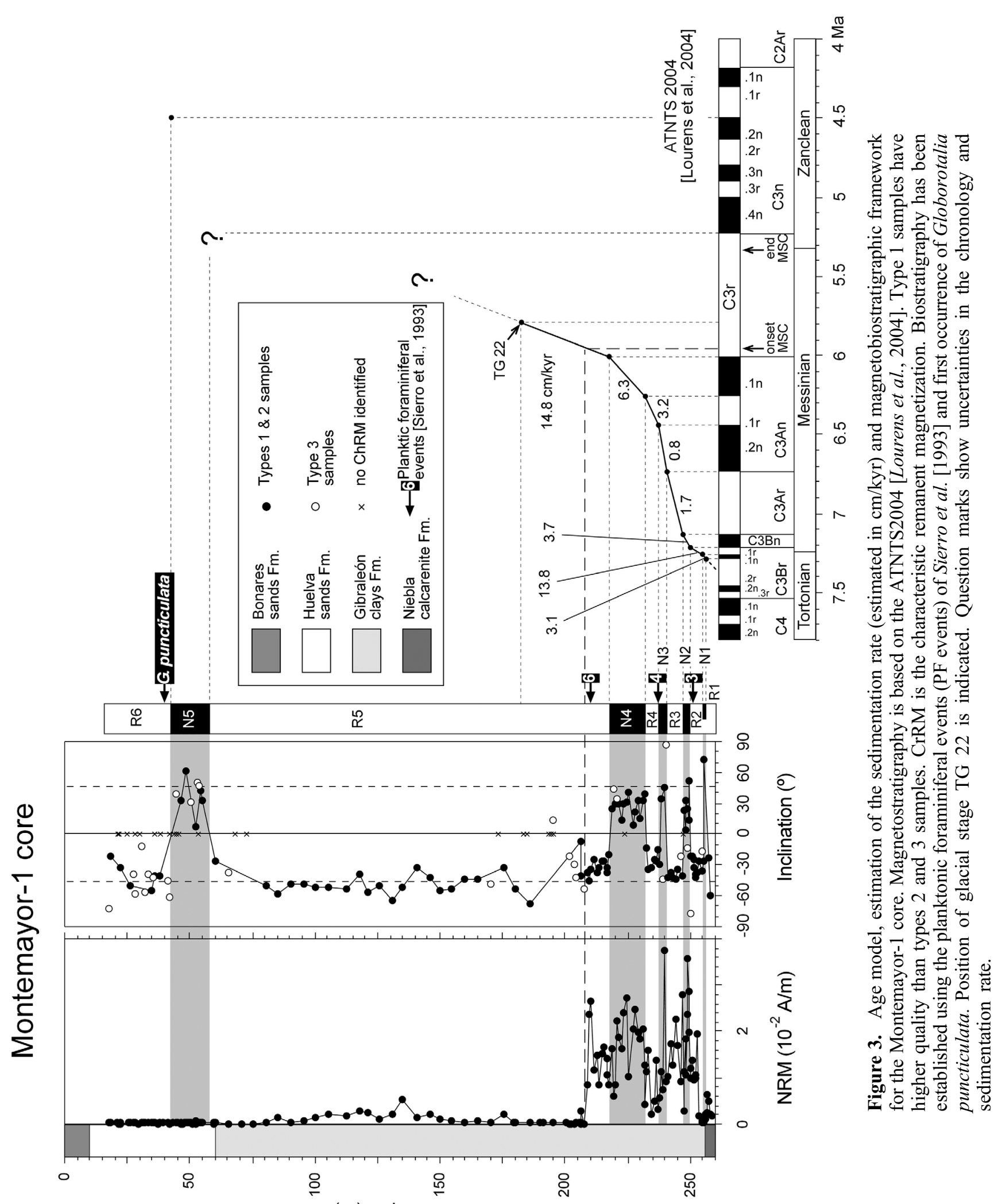

(ui) पıdə๐ 
preparation device for carbonates at the Leibniz-Laboratory for Radiometric Dating and Isotope Research, Kiel, Germany. Results are given in $\delta$-notation in per mil, and are reported on the Vienna Pee Dee belemnite (VPDB) scale. The VPDB scale is defined by a certain value of the National Bureau of Standards (NBS) carbonate standard NBS-19. On the basis of the international and lab-internal standard material, the analytical reproducibility is $< \pm 0.05 \%$ o for $\delta^{13} \mathrm{C}$, and $< \pm 0.07 \%$ for $\delta^{18} \mathrm{O}$.

\subsection{Spectral Analyses}

[16] Spectral analysis was performed in order to identify the nature and significance of periodic changes in the benthic $\delta^{18} \mathrm{O}$ record. The analysis was carried out in the time domain using the software PAST [Hammer et al., 2001] and the REDFIT procedure of Schulz and Mudelsee [2002]. This procedure allows assessing the spectral analysis with unevenly spaced samples. Spectral peaks over the $95 \%$ confidence interval (CI) were considered significant.

\section{Age Model}

[17] The age model of the Montemayor-1 core was established using a combination of paleomagnetism, biostratigraphy, and stable oxygen isotope stratigraphy (Figure 3 ). The reversed chron $\mathrm{C} 3 \mathrm{r}$ is almost continuously recorded since a discontinuity is detected close to the boundary between chrons $\mathrm{C} 3 \mathrm{r}$ and $\mathrm{C} 3 \mathrm{n}$, which prevent us from using this magnetostratigraphic reversal boundary as a chronological datum in the upper part of the core [Pérez-Asensio et al., 2012].

[18] To complete the age model above the normal magnetic chron C3An.1n, we have used the glacial stage TG 22 as a tie point, which was astronomically calibrated at 5.79 Ma [Krijgsman et al., 2004]. We identified this glacial stage by means of stable oxygen isotope stratigraphy (Figure 4). The benthic oxygen isotope record shows two distinctly pronounced "paired" glacial peak stages that we identify as the glacial stages TG 20 and TG 22 (Figure 4) according to the nomenclature established by Shackleton et al. [1995]. These two stages are easily identifiable because they are the most pronounced "paired" glacial peaks at the end of a progressively increasing trend in the $\delta^{18} \mathrm{O}$ record along the chron $\mathrm{C} 3 \mathrm{r}$ (Figure 4). Both the isotopic trend and the two "paired" glacial maxima are evident and have been observed in other cores at global scale including the Pacific Ocean [Shackleton et al., 1995], the Atlantic Ocean [Hodell et al., 2001; Vidal et al., 2002], as well as in sediments from the Rifian Corridors [Hodell et al., 1994].

[19] Using the TG 22 as a tie point in the chronological framework, the estimated age for the TG 20 based on the reconstructed sedimentation rate $(14.8 \mathrm{~cm} / \mathrm{kyr})$ is $5.75 \mathrm{Ma}$ (Figures 3 and 5). This age estimation is coincident with the age estimated by Krijgsman et al. [2004] using astronomical tuning.

[20] Further to the TG 20 and TG 22, we have identified the rest of the glacial stages following the nomenclature of Shackleton et al. [1995]. These authors found that the benthic $\mathrm{O}$ isotope record was controlled by 41-kyr cycles related to orbital obliquity. Hodell et al. [1994] also showed that the benthic isotope record from the Salé Briqueterie core at the Rifian Corridors reflects obliquity induced changes.
The benthic oxygen isotope record from the Montemayor-1 core is also mainly controlled by 41-kyr cycles related to orbital obliquity (Figure 6).

[21] Since the TG glacial stages of Shackleton et al. [1995] were related to obliquity, we use the same methodology to identify the rest of the TG stages in the chron C3r. Further, in order to confirm the reliability of the identification of TG 20 and TG 22 in the Montemayor-1 core, we plotted the benthic isotope record versus age (Ma), including the TG 22 datum (5.79 Ma), and counted obliquity cycles backward (Figure 5). Comparing the benthic oxygen isotope record from the Montemayor-1 core with its obliquity component (Figure 5) we identified up to stage TG 32 for chron C3r. However, Hodell et al. [1994] and van der Laan et al. [2005] recognized one extra obliquity cycle, up to TG 34 stage. The discrepancy in just one obliquity cycle (1 glacial stage and 1 interglacial stage) can be due to the fact that Hodell et al. [1994] identified glacial stages versus depth instead of time. This could result in counting cycles of different periodicities. On the other hand, van der Laan et al. [2005], considered the glacial stage TG 30, which is a precession-related signal, at the same level of the rest of the obliquity-related cycles.

\section{Results}

[22] The benthic oxygen isotope record shows stable values around $1 \%$ before $6.35 \mathrm{Ma}$, and then it decreases reaching a minimum of $-0.93 \%$ at $6.18 \mathrm{Ma}$ (Figure 7 ). After $6.18 \mathrm{Ma}$, it exhibits fluctuations with a trend toward heavier values reaching the maximum values at $5.79 \mathrm{Ma}$ (TG 22), and then it decreases toward lighter values (Figure 7). The benthic stable $\mathrm{O}$ isotope curves of the Montemayor-1 core and site 1085 [Vidal et al., 2002] reveal different trends for the time interval before $6.18 \mathrm{Ma}$ (Figure 5). On the contrary, both curves show a parallel trend with similar fluctuations after 6.18 Ma. In this interval, heavy values of $\delta^{18} \mathrm{O}$ from the Montemayor- 1 core can be easily matched with glacial peaks from site 1085 (Figure 5).

[23] The planktonic oxygen isotope record exhibits a fluctuating trend with values $\leq 0 \%$ before $6.18 \mathrm{Ma}$ and values $>0 \%$ after this age (Figure 7 ). Both the benthic and planktonic $\mathrm{O}$ isotopic curves follow different trends before 6.18 Ma. After 6.18 Ma, the planktonic O isotopic curve parallels that of the benthic one except for some low values around $5.79 \mathrm{Ma}$ (Figure 7). The similar trend of both records is confirmed by a statistically significant positive correlation $(\rho=0.415)$. The $\Delta \delta^{18} \mathrm{O}_{\text {benthic-planktonic }}\left(\Delta \delta^{18} \mathrm{O}_{\mathrm{b}-\mathrm{p}}\right)$ curve reflects these differences before and after $6.18 \mathrm{Ma}$ between the benthic and planktonic $\mathrm{O}$ isotope values, being higher before $6.18 \mathrm{Ma}$ (Figure 7). The difference reaches average values close to 0 at around $6.2 \mathrm{Ma}$ (Figure 7).

[24] The planktonic carbon isotope record exhibits significant fluctuations with average values around $-0.8 \%$ before 6.18 Ma (Figure 7). After 6.18 Ma, the $\delta^{13} \mathrm{C}$ decreases reaching its lowest values from 6.05 to $5.85 \mathrm{Ma}$. Then, it drastically increases from average values of $-1 \%$ to $0 \%$ at $5.85 \mathrm{Ma}$, and remains with relatively high average values around 0 until 5.77 Ma. At this age, another carbon shift took place recovering average values of $-1 \%$ o (Figure 7 ). The benthic carbon isotope record shows fluctuations with average values around $0.4 \%$ before $6.18 \mathrm{Ma}$. After 6.18 Ma, 


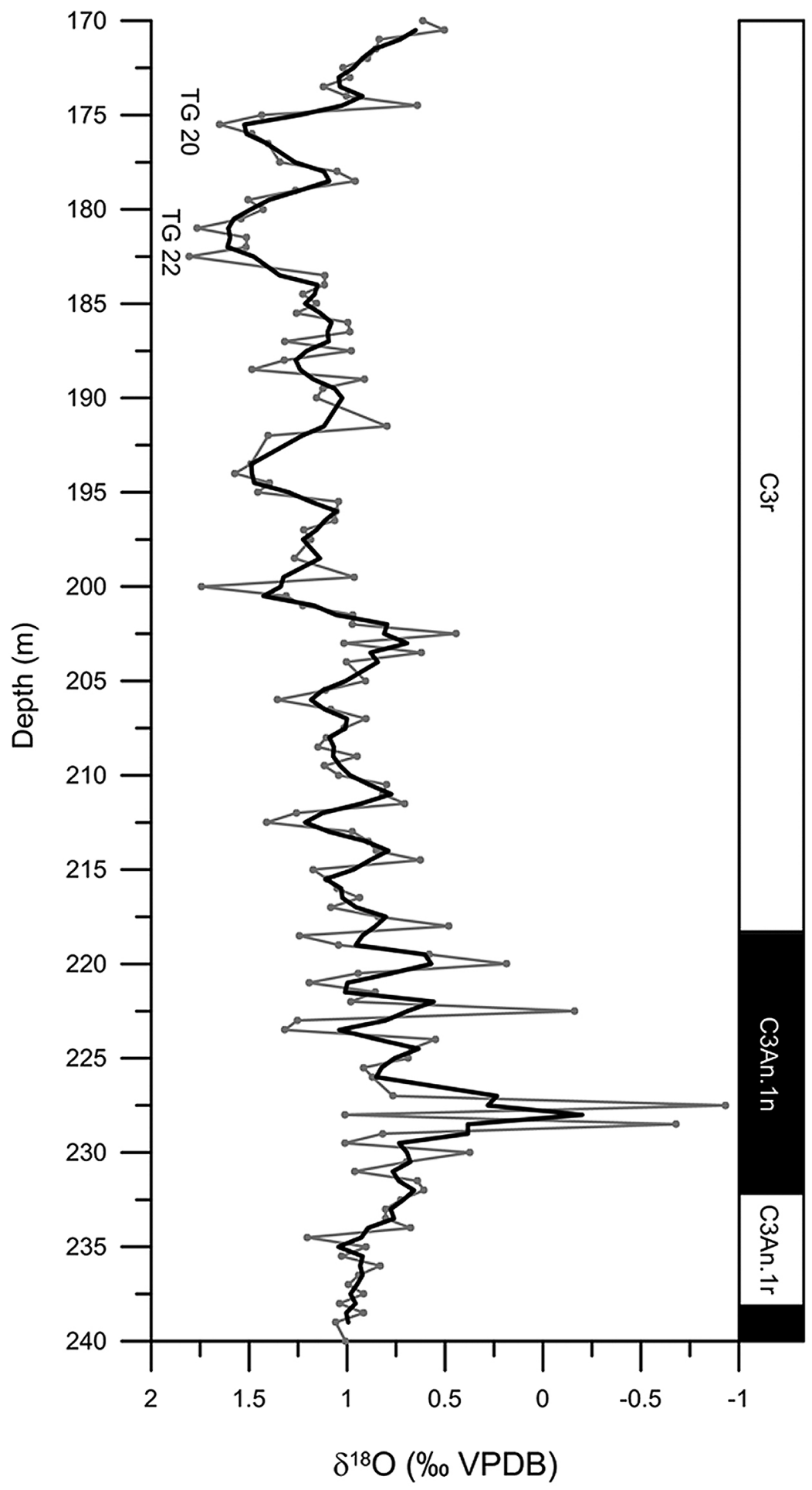

Figure 4. Benthic (Cibicidoides pachydermus) stable oxygen isotope record versus core depth (gray line) and three-point running average of the benthic oxygen isotope record (black line) of the Montemayor-1 core. Glacial stages TG 20 and TG 22 defined by Shackleton et al. [1995] in benthic oxygen isotope record of the ODP site 846 are indicated. 


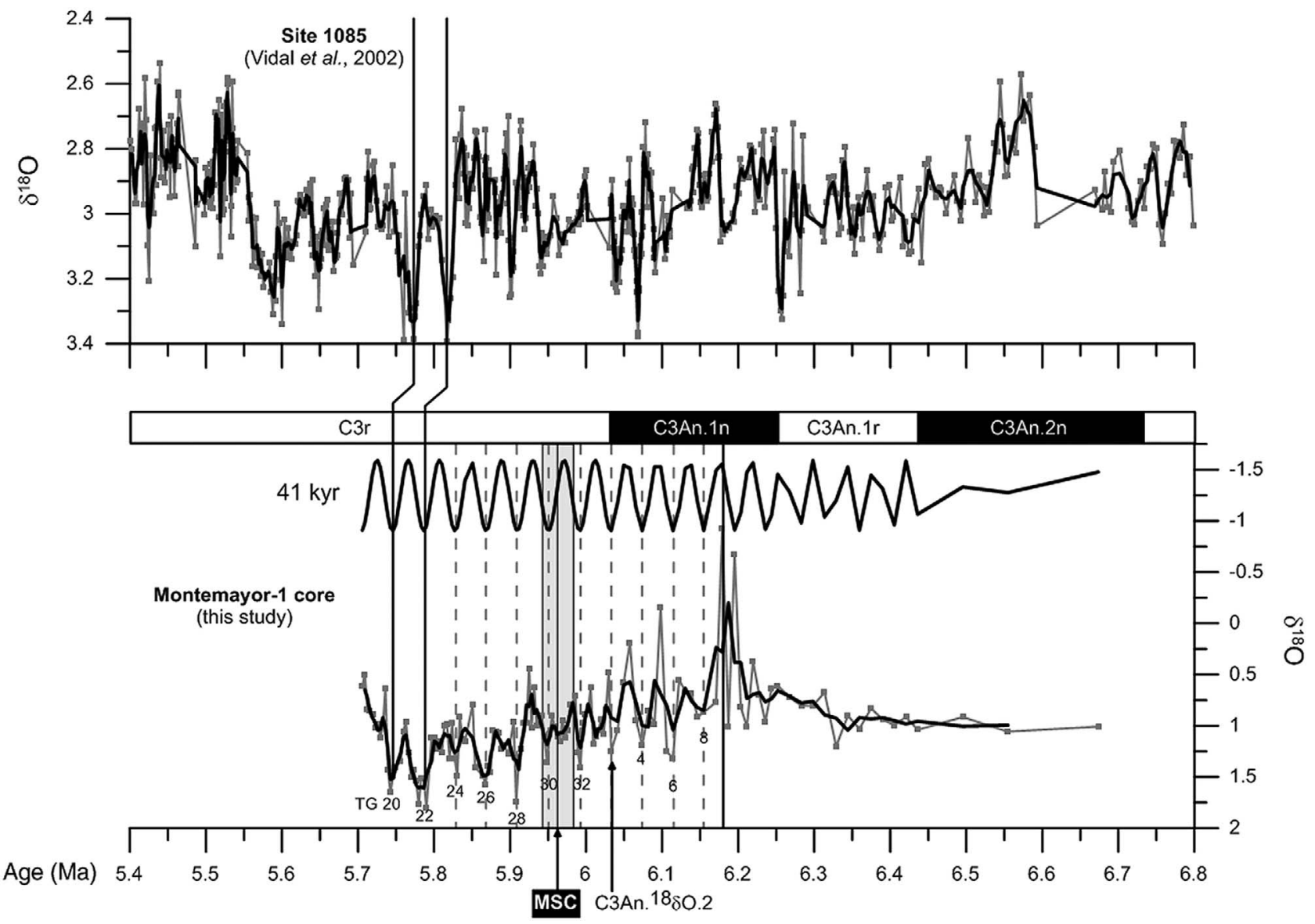

Figure 5. Benthic (Cibicidoides pachydermus) stable oxygen isotope record versus time (gray lines) and three-point running average of the benthic oxygen isotope record (black lines) from the Site 1085 [Vidal et al., 2002] and Montemayor-1 core. The obliquity component of the benthic isotope record is extracted by sinusoidal curve fitting with a period of $41 \mathrm{kyr}$. The onset of the Messinian salinity crisis (MSC) is indicated (vertical gray bar in the lower diagram). The vertical black line at $6.18 \mathrm{Ma}$ marks the end of the Atlantic-Mediterranean connection through the Guadalhorce Corridor. Glacial stages from TG 20 to TG 32 defined by Shackleton et al. [1995] and from C3An. $\delta^{18} \mathrm{O} .2$ to C $3 \mathrm{An} . \delta^{18} \mathrm{O} .8$ according to the nomenclature used in Hodell et al. [1994] are indicated. The two vertical black solid lines mark glacial stages TG 20 and 22 from the Montemayor-1 core and Site 1085. Vertical gray dashed lines mark glacial stages and the obliquity component of the benthic oxygen isotope record of the Montemayor-1 core.

the $\delta^{13} \mathrm{C}$ decreases reaching its lowest values from 6 to 5.9 Ma. Finally, it increases and remains with relatively high values around $0.4 \%$ from 5.9 to $5.7 \mathrm{Ma}$ (Figure 7).

\section{Discussion}

\subsection{Identification of the MOW in the Northeastern Atlantic and Age of the Closure of the Guadalhorce Corridor}

\subsubsection{MOW Presence Before 6.18 Ma}

[25] The benthic $\mathrm{O}$ isotopic values from the Montemayor1 core depart from the fluctuating global trend, based on Vidal et al. [2002], from the base of the studied interval to $6.18 \mathrm{Ma}$ (Figure 5). The presence of a dense, i.e., highly saline, bottom water mass affecting the study area might account for the observed deviation toward heavier values in the $\mathrm{O}$ isotope record.

[26] The Montemayor-1 core site is located adjacent to the Guadalhorce Corridor, the last Atlantic-Mediterranean gateway providing a connection between the Mediterranean and Atlantic oceans through the Betic Cordillera prior to the onset of the MSC (Figure 8a). Based on the vicinity of the core site to this gateway it appears most likely that the benthic habitats of the study area were bathed by the highly saline MOW prior to $6.18 \mathrm{Ma}$ (Figure 8a).

[27] In the Montemayor-1 core, benthic $\mathrm{O}$ values remain approximately constant at around $1 \%$ before $6.35 \mathrm{Ma}$. This suggests a more or less constant MOW flux as indicated by the scarcity of reactivation surfaces in the sedimentary structures of the Guadalhorce Corridor [Martín et al., 2001]. The benthic stable $\mathrm{O}$ isotope values of $1 \%$ reflect the density of the MOW that is the product of mixing between the exported Mediterranean water and the ambient Atlantic water. This value is in the range of recent benthic stable $\mathrm{O}$ isotope values of the upper core of the MOW, which ranges between 1 and 2\%o [Rogerson et al., 2011]. Before 6.35 Ma the exchange through the Guadalhorce Corridor is expected to be maximal because of the increased density between the 


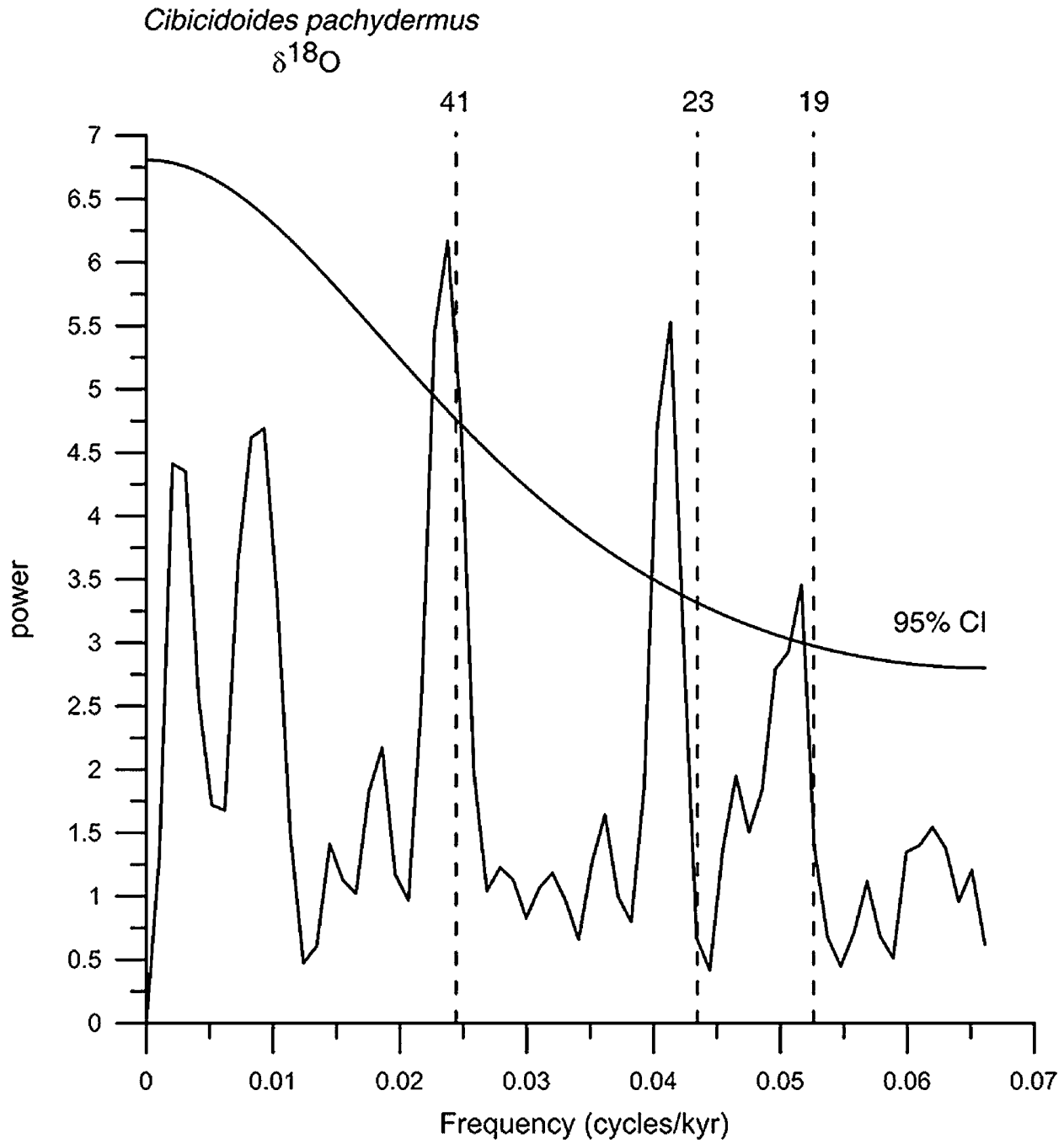

Figure 6. Power spectrum of the benthic (Cibicidoides pachydermus) stable oxygen isotope record of the Montemayor- 1 core with main orbital periodicities indicated in kiloyears. The $95 \%$ confidence interval (CI) is indicated.

MOW and Atlantic surface waters $\left(\Delta \delta^{18} \mathrm{O}_{\mathrm{b}-\mathrm{p}}\right)$ and the high sea level indicated by the $\mathrm{P} / \mathrm{B}$ ratios (Figure 7). The benthic $\mathrm{C}$ isotope record could partially reflect MOW activity. Using the modern analogue, high values of benthic $\delta^{13} \mathrm{C}$ are associated to MOW because of the low residence time of this water mass [Vergnaud-Grazzini, 1983; Schönfeld and Zahn, 2000; Raddatz et al., 2011; Rogerson et al., 2011]. Thus, relatively high benthic $\mathrm{C}$ isotopic values around 6.4-6.5 Ma might be the result of increased MOW presence (Figure 7).

[28] The presence of the MOW before $6.18 \mathrm{Ma}$ is also supported by the paleobathymetry of the study area during this period. At the present day, the MOW entering the Atlantic flows along the western Iberian continental slope between 400 and 1,500 $\mathrm{m}$ water depth [Schönfeld and Zahn, 2000; Llave et al., 2006]. In the study area, the presence of R-mode Anomalinoides flinti assemblage and Planulina ariminensis before $6.18 \mathrm{Ma}$ (below $227.5 \mathrm{~m}$ core depth in Pérez-Asensio et al., 2012) indicates that the current flowed along the middle and upper slope [Pérez-Asensio et al., 2012]. This is within the depth range of MOW flow at the present day.
[29] A comparison between benthic and planktonic $\mathrm{O}$ isotopic records from the Montemayor- 1 core offers another indication of the MOW presence before $6.18 \mathrm{Ma}$. The decoupling and high difference between the benthic and planktonic O isotopic signals before $6.18 \mathrm{Ma}$ (Figure 7) are indicative of a two-layer water column with the presence of MOW at the seafloor. Moreover, the lowest sedimentation rates are estimated before $6.18 \mathrm{Ma}$ (Figure 3). Thus, winnowing by the MOW might most likely account for this result.

6.1.2. Response of the MOW Plume to the Restriction of the Guadalhorce Corridor (6.35 to 6.18 Ma)

[30] Between 6.35 and $6.18 \mathrm{Ma}$, the benthic O isotopic record underwent a significant negative excursion of about $2 \%$, from $1 \%$ o to minimum of $-0.93 \%$ (Figures 5 and 7 ). This noteworthy isotopic shift suggests a MOW product with a lighter $\mathrm{O}$ isotopic signature. The ambient Atlantic water has a lower density than the MOW [Price and O'NeillBaringer, 1994]. Hence, the local minimum in the benthic $\delta^{18} \mathrm{O}$ from 6.35 to $6.18 \mathrm{Ma}$ could be explained by a higher proportion of the lighter ambient Atlantic water in the final 


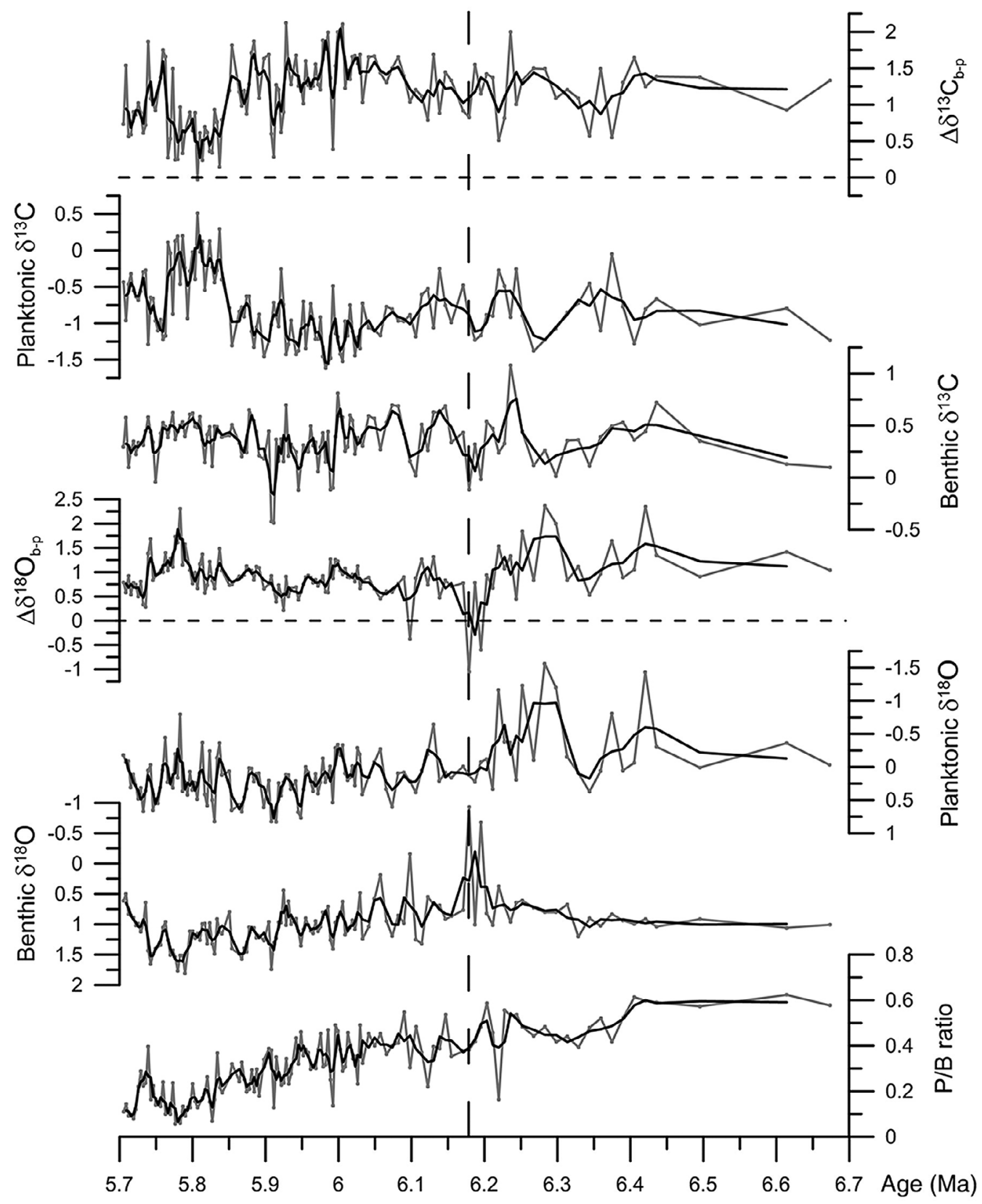

Figure 7. Benthic (Cibicidoides pachydermus) and planktonic (Globigerina bulloides) $\delta^{18} \mathrm{O}$ and $\delta^{13} \mathrm{C}$ records in \% VPDB, difference between $\delta^{18} \mathrm{O}$ and $\delta^{13} \mathrm{C}$ values of benthic and planktonic foraminifera $\left(\Delta \delta^{18} \mathrm{O}_{\mathrm{b}-\mathrm{p}}\right.$ and $\Delta \delta^{13} \mathrm{C}_{\mathrm{b}-\mathrm{p}}$ ), as well as the planktonic-benthic ratio ( $\mathrm{P} / \mathrm{B}$ ratio) versus time (gray lines) and three-point running average (black lines) of the Montemayor-1 core. The vertical dashed line at 6.18 Ma marks the end of the Atlantic-Mediterranean connection through the Guadalhorce Corridor.

MOW product as occurs at present day outside the upper core of the MOW plume [Rogerson et al., 2011]. In addition, this fact could reflect a gradual reduction in the exchange through the Guadalhorce Corridor as it is indicated by the reduction of density between the MOW and the Atlantic surface waters $\left(\Delta \delta^{18} \mathrm{O}_{\mathrm{b}-\mathrm{p}}\right)$ and relatively low sea level (Figure 7). The reduced exchange from 6.35 to $6.18 \mathrm{Ma}$ is also reflected by the decrease in the benthic $\mathrm{C}$ isotopes (Figure 7). Similarly, the diminished outflow of Mediterranean waters in the Rifian Corridors is indicated by a negative excursion in the planktonic $\mathrm{C}$ isotopes at $6.0 \mathrm{Ma}$ [van der Laan et al., 2012].

[31] Alternatively, the local minimum in the benthic $\delta^{18} \mathrm{O}$ might reflect the isotopic signature of less dense Atlantic waters. Increased salinity of Mediterranean source waters due to the restriction of the Guadalhorce Corridor could produce a denser MOW that mixes faster with ambient Atlantic waters reducing its density and consequently shoaling on the slope [Rogerson et al., 2012]. Therefore, the location of the Montemayor-1 core would be beneath the MOW between 6.35 and $6.18 \mathrm{Ma}$. Our data from the 

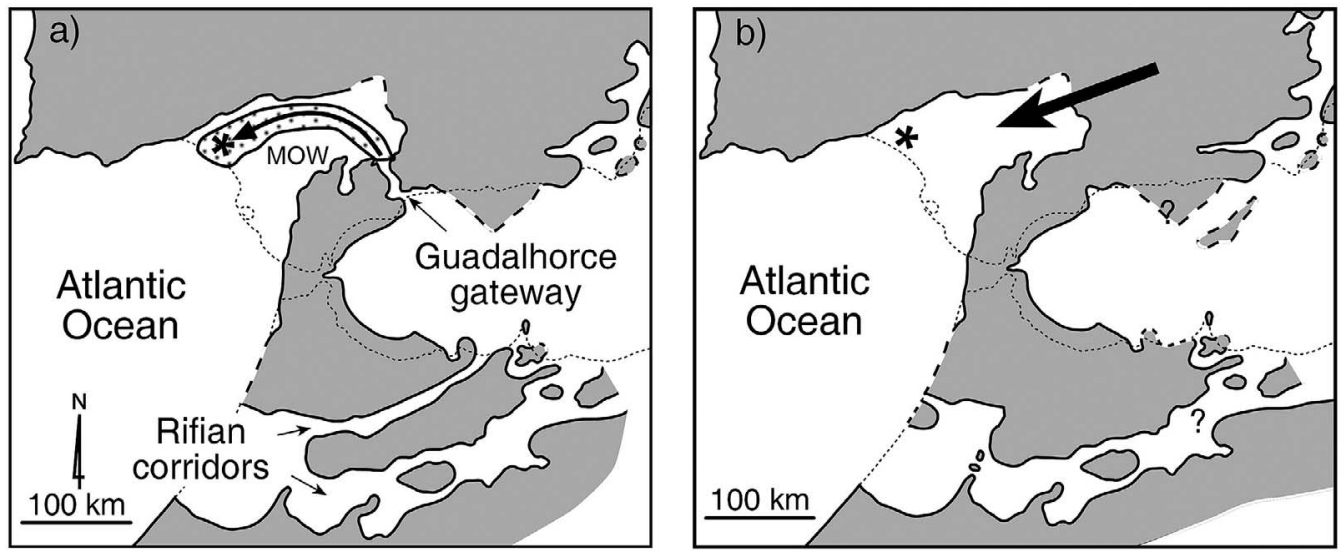

Figure 8. Paleogeographic and paleoceanographic evolution of the lower Guadalquivir Basin during the Messinian (based on Martín et al., 2009): (a) situation before $6.18 \mathrm{Ma}$, when the Mediterranean Outflow Water (MOW) reaches the studied core (asterisk) and (b) situation after 6.18 Ma, when the MOW was interrupted. The black thick arrow marks the progradation of the main depositional systems along the axis of the Guadalquivir Basin.

Montemayor-1 core do not allow us to rule out any of these two alternative explanations.

\subsubsection{Cessation of the MOW at 6.18 Ma}

[32] After $6.18 \mathrm{Ma}$, the benthic $\delta^{18} \mathrm{O}$ parallels that of the global benthic $\mathrm{O}$ record, with main glacial stages easily distinguishable in both records (Figure 5). Therefore, benthic $\mathrm{O}$ isotopic values at the study area were primarily controlled by global glacioeustatic fluctuations. Most likely, the striking change in the $\delta^{18} \mathrm{O}$ record at $6.18 \mathrm{Ma}$ can be linked with the cessation of the dense MOW influence in the study area (Figure $8 b$ ).

[33] A comparison between benthic and planktonic $\mathrm{O}$ isotopic records from the Montemayor-1 core also supports the interruption of the MOW after 6.18 Ma. Benthic and planktonic $\mathrm{O}$ isotopic values covary after $6.18 \mathrm{Ma}$ indicating enhanced vertical mixing and absence of MOW. This is also supported by low $\Delta \delta^{18} \mathrm{O}_{\mathrm{b}-\mathrm{p}}$ and positive statistical correlation between benthic and planktonic $\mathrm{O}$ isotopic values $(\rho=0.415)$ (Figure 7). The covariation and the decreasing difference between planktonic and benthic $\mathrm{O}$ isotopes might have also been favored by the shallowing-upward trend that reduces the difference between benthic and planktonic isotopic values.

[34] Moreover, sedimentation rate could be affected by the interruption of the $\mathrm{MOW}$ at $6.18 \mathrm{Ma}$. After this date, sedimentation rates drastically increases from 6.3 to $14.8 \mathrm{~cm} / \mathrm{kyr}$ (Figure 3) likely due to the interruption of the MOW and the resulting progradation of depositional systems along the axis of the Guadalquivir Basin [Sierro et al., 1996] (Figure 8b).

[35] The closure of this corridor at $6.18 \mathrm{Ma}$ caused the final interruption of MOW. The observed age for the end of this Betic gateway is consistent with planktonic foraminifera recorded in the sediments filling the Guadalhorce Corridor that indicate that the strait was open at least from 7.2 to $6.3 \mathrm{Ma}$ [Martín et al., 2001]. Further, it is also coincident with the first land mammal exchange between Africa and the Iberian Peninsula prior to the MSC taking place at $6.1 \mathrm{Ma}$ [Garcés et al., 1998]. Therefore, according to our data, the closure of the Guadalhorce Corridor (6.18 Ma) predates by about 220-kyr the onset of the MSC, dated at $5.96 \pm$ 0.02 Ma by Krijgsman et al. [1999b].

\subsection{Impact of the MOW on the Eastern North Atlantic Ocean Circulation}

[36] The MOW is essential to maintain the meridional overturning circulation (AMOC) because it increases the North Atlantic density gradient and can restart the AMOC after its collapse [Rogerson et al., 2012]. It appears likely that any fluctuation of the MOW can alter the AMOC. During the Messinian period, the increase of the NADW presence in the South Atlantic Ocean between 6.6 and 6.0 Ma [Billups, 2002] suggests an enhanced NADW formation due to the suspected salinity increase of the MOW before the closure of the Atlantic-Mediterranean gateways. During this interval, MOW affected our study area before the closure of the Guadalhorce Corridor at $6.18 \mathrm{Ma}$ (Figures 5 and 7). It has to be mentioned however, that the increase in NADW flow in the South Atlantic Ocean could have also been caused by the shoaling of the Central American Seaway (Panamanian Seaway) during the middlelate Miocene [Billups, 2002; Nisancioglu et al., 2003; Butzin et al., 2011].

[37] The MOW is predominantly fed by the LIW [Bryden and Stommel, 1984]. During the Quaternary, cold stadials have been associated with production of a denser LIW [Cacho et al., 2000] that enhanced the current activity and depth of settling of the MOW [Schönfeld and Zahn, 2000; Rogerson et al., 2005]. Similarly, during the late Miocene global cooling [Zachos et al., 2001; Murphy et al., 2009] a denser LIW could have enhanced the MOW via increasing its buoyancy loss, which is consistent with the observed increase of the NADW formation and AMOC intensification during this time interval.

[38] The final closure of the Guadalhorce Corridor might have produced a dramatic reduction of the MOW, which then could only flow through the Rifian Corridors until their final closure at around 6.0 Ma [Krijgsman et al., 1999a]. This led to a diminished NADW production as is recorded between 6.0 and 5.5 Ma in the South Atlantic [Billups, 
2002]. Concomitantly, the cessation of the MOW increased the freshwater input in the North Atlantic reducing or interrupting the NADW formation [Rahmstorf, 1998]. This might have had a critical impact on the AMOC, global thermohaline circulation and global climate [Bethoux et al., 1999]. Specifically, the reduction or interruption of the NADW by MOW cessation would reduce the AMOC leading to northern hemisphere cooling [Clark et al., 2002]. This is supported by development of northern hemisphere ice sheets in Greenland margin [Fronval and Jansen, 1996; Thiede et al., 1998].

[39] Finally, with the restoration of the Atlantic-Mediterranean connections through the Strait of Gibraltar, the MOW enhanced the NADW formation as it is indicated by the rise in NADW flow around the Miocene-Pliocene boundary in the South Atlantic and the western equatorial Atlantic Ocean [King et al., 1997; Billups, 2002].

\section{Conclusions}

[40] The Messinian stable isotope records from the Montemayor-1 core located in the lower Guadalquivir Basin (SW Spain) allow the accurate dating of the closure of the Guadalhorce Corridor, the last Betic Corridor connecting the Atlantic and the Mediterranean before the MSC, at 6.18 Ma.

[41] Before the closure of the Guadalhorce Corridor, the export of highly saline intermediate waters as MOW contributed to increased NADW formation in the North Atlantic Ocean. During this period, constant benthic $\delta^{18} \mathrm{O}$ values that depart from the global glacioeustatic trend, high $\Delta \delta^{18} \mathrm{O}_{\mathrm{b}-\mathrm{p}}$, and low sedimentation rates indicate a strong water stratification and bottom water winnowing due to the MOW flow. After the closure of the corridor, benthic $\delta^{18} \mathrm{O}$ values, which parallel that of the global glacioeustatic curve, low $\Delta \delta^{18} \mathrm{O}_{\mathrm{b}}$ $\mathrm{p}$, and high sedimentation rates suggest an improved vertical mixing of the water column and interruption of MOW. Changes in the stable $\mathrm{O}$ isotope composition of the subsurface North Atlantic water masses during this time interval are primarily controlled by glacioeustatic processes. The cessation of the MOW might have resulted in decreased NADW formation between 6.0 and $5.5 \mathrm{Ma}$ weakening the AMOC and promoting northern hemisphere cooling. Then, the restoration of the MOW due to the opening of the Strait of Gibraltar around the Miocene-Pliocene boundary would have favored an enhanced NADW formation.

[42] Acknowledgments. We acknowledge the comments provided by reviewers Michael Rogerson and Marit-Solveig Seidenkrantz which substantially improved the quality of an earlier version of the manuscript. This paper is part of the research projects CGL2010-20857 and CGL200911539/BTE of the Ministerio de Ciencia e Innovación of Spain and the Research Group RNM-190 of the Junta de Andalucía. J.N.P.A. has been funded by a research F.P.U. scholarship (ref. AP2007-00345) provided by the Ministerio de Educación of Spain. We are grateful to N. Andersen (Leibniz-Laboratory, Kiel, Germany) for stable isotope analysis. We also thank L. Vidal who provided the stable isotope data of benthic foraminifera from the ODP Site 1085 (SE Atlantic).

\section{References}

Abouchami, W., S. J. G. Galer, and A. Koschinsky (1999), Pb and Nd isotopes in NE Atlantic Fe-Mn crusts: Proxies for trace metal paleosources and paleocean circulation, Geochim. Cosmochim. Acta, 63, 1489-1505, doi:10.1016/S0016-7037(99)00068-X.

Aguirre, J. (1992), Evolución de las asociaciones fósiles del Plioceno marino de Cabo Roche (Cádiz), Rev. Esp. Paleontol., Extra, 3, 3-10.
Aguirre, J. (1995), Implicaciones paleoambientales y paleogeográficas de dos discontinuidades estratigráficas en los depósitos pliocénicos de Cádiz (SW de España), Rev. Soc. Geol. Esp., 8, 161-174.

Aguirre, J., J. C. Braga, and J. M. Martín (1993), Algal nodules in the Upper Pliocene deposits at the coast of Cadiz (S Spain), in Studies on Fossil Benthic Algae, Boll. Soc. Paleontol. Ital., Spec. Vol., vol. 1, edited by F. Barattolo, P. De Castro, and M. Parente, pp. 1-7, Mucchi, Modena, Italy.

Aguirre, J., C. Castillo, F. J. Férriz, J. Agustí, and O. Oms (1995), Marinecontinental magnetobiostratigraphic correlation of the Dolomys subzone (middle of Late Ruscinian): Implications for the Late Ruscinian age, Palaeogeogr. Palaeoclimatol. Palaeoecol., 117, 139-152, doi:10.1016/ 0031-0182(94)00123-P.

Aguirre, J., J. C. Braga, and J. M. Martín (2007), El Mioceno marino del Prebético occidental (Cordillera Bética, SE de España): Historia del cierre del Estrecho Norbético, in XIII Jornadas de la Sociedad Española de Paleontología: Guía de Excursiones, edited by J. Aguirre et al., pp. 53-66, Inst. Geol. y Min. de Esp., Univ. de Granada, Granada, Spain. Benson, R. H., K. Rakic-El Bied, and G. Bonaduce (1991), An important current reversal (influx) in the Rifian corridor (Morocco) at the TortonianMessinian Boundary: The end of Tethys ocean, Paleoceanography, 6, 165-192, doi:10.1029/90PA00756.

Bethoux, J. P., B. Gentili, P. Morin, E. Nicolas, C. Pierre, and D. Ruiz-Pino (1999), The Mediterranean Sea: A miniature ocean for climatic and environmental studies and a key for the climatic functioning of the North Atlantic, Prog. Oceanogr., 44, 131-146, doi:10.1016/S0079-6611(99) 00023-3.

Betzler, C., J. C. Braga, J. M. Martín, I. M. Sánchez-Almazo, and S. Lindhorst (2006), Closure of a seaway: Stratigraphic record and facies (Guadix basin, southern Spain), Int. J. Earth Sci., 95, 903-910, doi:10.1007/ s00531-006-0073-y

Bigg, G. R., and M. R. Wadley (2001), Millennial-scale variability in the oceans: An ocean modelling view, J. Quat. Sci., 16, 309-319, doi:10.1002/jqs.599.

Bigg, G. R., T. D. Jickells, P. S. Liss, and T. J. Osborn (2003), The role of the oceans in climate, Int. J. Climatol., 23, 1127-1159, doi:10.1002/ joc. 926 .

Billups, K. (2002), Late Miocene through early Pliocene deep water circulation and climate change viewed from the sub-Antarctic South Atlantic, Palaeogeogr. Palaeoclimatol. Palaeoecol., 185, 287-307, doi:10.1016/ S0031-0182(02)00340-1.

Braga, J. C., J. M. Martín, and J. Aguirre (2002), Tertiary. Southern Spain, in The Geology of Spain, edited by W. Gibbons and T. Moreno, pp. 320-327, Geol. Soc., London.

Braga, J. C., J. M. Martín, and C. Quesada (2003), Patterns and average rates of late Neogene-Recent uplift of the Betic Cordillera, SE Spain, Geomorphology, 50, 3-26, doi:10.1016/S0169-555X(02)00205-2.

Braga, J. C., J. M. Martín, R. Riding, J. Aguirre, I. M. Sánchez-Almazo, and J. Dinarès-Turell (2006), Testing models for the Messinian salinity crisis: The Messinian record in Almería, SE Spain, Sediment. Geol., 188-189, 131-154, doi:10.1016/j.sedgeo.2006.03.002.

Braga, J. C., J. M. Martín, J. Aguirre, C. D. Baird, I. Grunnaleite, N. B. Jensen, A. Puga-Bernabéu, G. Saelen, and M. R. Talbot (2010), MiddleMiocene (Serravallian) temperate carbonates in a seaway connecting the Atlantic Ocean and the Mediterranean Sea (North Betic Strait, S Spain), Sediment. Geol., 225, 19-33, doi:10.1016/j.sedgeo.2010.01.003.

Brown, J., A. Colling, D. Park, J. Phillips, D. Rothery, and J. Wright (1989), Ocean Circulation, Pergamon, Oxford, U. K.

Bryden, H. L., and H. M. Stommel (1984), Limiting processes that determine basic features of the circulation in the Mediterranean Sea, Oceanol. Acta, 7, 289-296.

Butzin, M., G. Lohmann, and T. Bickert (2011), Miocene ocean circulation inferred from marine carbon cycle modeling combined with benthic isotope records, Paleoceanography, 26, PA1203, doi:10.1029/2009PA001901.

Cacho, I., J. O. Grimalt, F. J. Sierro, N. Shackleton, and M. Canals (2000), Evidence for enhanced Mediterranean thermohaline circulation during rapid climatic coolings, Earth Planet. Sci. Lett., 183, 417-429, doi:10.1016/S0012-821X(00)00296-X.

Clark, P. U., N. G. Pisias, T. F. Stocker, and A. J. Weaver (2002), The role of the thermohaline circulation in abrupt climate change, Nature, 415, 863-869, doi: $10.1038 / 415863 a$.

Esteban, M., J. C. Braga, J. M. Martín, and C. Santisteban (1996), Western Mediterranean reef complexes, in Models for Carbonate Stratigraphy from Miocene Reef Complexes of Mediterranean Regions. Concepts Sedimentol. Paleontol., vol. 5., edited by E. K. Franseen et al., pp. 55-72, Soc. of Econ. Paleontol. and Mineral., Tulsa, Okla.

Estrada, F., G. Ercilla, C. Gorini, B. Alonso, J. T. Vázquez, D. GarcíaCastellanos, C. Juan, A. Maldonado, A. Ammar, and M. Elabbassi (2011), Impact of pulsed Atlantic water inflow into the Alboran Basin 
at the time of the Zanclean flooding, Geo Mar. Lett., 31, 361-376, doi:10.1007/s00367-011-0249-8.

Fronval, T., and E. Jansen (1996), Late Neogene paleoclimates and paleoceanography in the Iceland-Norwegian Sea: Evidence from the Iceland and VØring Plateaus, Proc. Ocean Drill. Program, Sci. Results, 151, 455-468, doi:10.2973/odp.proc.sr.151.134.1996.

Garcés, M., W. Krijgsman, and J. Agustí (1998), Chronology of the late Turolian deposits of the Fortuna basin (SE Spain): Implications for the Messinian evolution of the eastern Betics, Earth Planet. Sci. Lett., 163, 69-81, doi:10.1016/S0012-821X(98)00176-9.

González-Delgado, J. A., J. Civis, C. J. Dabrio, J. L. Goy, S. Ledesma J. Pais, F. J. Sierro, and C. Zazo (2004), Cuenca del Guadalquivir, in Geología de España, edited by J. A. Vera, pp. 543-550, SGE-IGME, Madrid.

Hammer, Ø., D. A. T. Harper, and P. D. Ryan (2001), PAST: Paleontological Statistics software package for education and data analysis [online] Palaeontol. Elec., 4(1), Article 4.

Hernández-Molina, F. J., et al. (2006), The contourite depositional system of the Gulf of Cádiz: A sedimentary model related to the bottom current activity of the Mediterranean outflow water and its interaction with the continental margin, Deep Sea Res., Part II, 53, 1420-1463, doi:10.1016/j.dsr2.2006.04.016.

Hernández-Molina, F. J., N. Serra, D. A. V. Stow, E. Llave, G. Ercilla, and D. Van Rooij (2011), Along-slope oceanographic processes and sedimentary products around the Iberian margin, Geo Mar. Lett., 31, 315-341, doi:10.1007/s00367-011-0242-2.

Hodell, D. A., R. H. Benson, D. V. Kent, A. Boersma, and K. Rakic-El Bied (1994), Magnetostratigraphic, biostratigrahic, and stable isotope stratigraphy of an Upper Miocene drill core from the Salé Briqueterie (northwestern Morocco): A high-resolution chronology for the Messinian stage, Paleoceanography, 9, 835-855, doi:10.1029/94PA01838.

Hodell, D. A., J. H. Curtis, F. J. Sierro, and M. E. Raymo (2001), Correlation of late Miocene to early Pliocene sequences between the Mediterranean and North Atlantic, Paleoceanography, 16, 164-178, doi:10.1029/ 1999PA000487.

Hsü, K. J., W. B. F. Ryan, and M. B. Cita (1973), Late Miocene Desiccation of the Mediterranean, Nature, 242, 240-244, doi:10.1038/242240a0

Hsü, J. K., L. Montadert, D. Bernoulli, M. B. Cita, A. Erickson, R. E. Garrison, R. B. Kidd, F. Mélières, C. Müller, and R. Wright (1977), History of the Mediterranean salinity crisis, Nature, 267, 399-403, doi:10.1038/267399a0.

Huang, T. C., and D. J. Stanley (1972), Western Alboran Sea: Sediment dispersal, ponding and reversal of currents, in The Mediterranean Sea A Natural Sedimentation Laboratory, edited by D. J. Stanley et al., pp. 521-559, Dowden Hutchinson Ross, Stroudsburg, Pa.

Keigwin, L. D., M. P. Aubry, and D. V. Kent (1987), North Atlantic late Miocene stable-isotope stratigraphy, biostratigraphy, and magnetostratigraphy, Initial Rep. Deep Sea Drill. Proj., 94, 935-963.

Khélifi, N., M. Sarnthein, N. Andersen, T. Blanz, M. Frank, D. GarbeSchönberg, B. A. Haley, R. Stumpf, and M. Weinelt (2009), A major and long-term Pliocene intensification of the Mediterranean outflow, 3.5-3.3 Ma ago, Geology, 37, 811-814, doi:10.1130/G30058A.1.

King, T. A., W. G. Ellis Jr., D. W. Murray, N. J. Shackleton, and S. Harris (1997), Miocene evolution of carbonate sedimentation at the Ceara rise A multivariate data/proxy approach, in Proc. Ocean Drill. Program Sci. Results, 154, 349-365, doi:10.2973/odp.proc.sr.154.116.1997

Krijgsman, W., C. G. Langereis, W. J. Zachariasse, M. Boccaletti, G. Moratti, R. Gelati, S. Iaccarino, G. Papani, and G. Villa (1999a), Late Neogene evolution of the Taza- Guercif Basin (Rifian Corridor, Morocco) and implications for the Messinian salinity crisis, Mar. Geol., 153, 147-160, doi:10.1016/S0025-3227(98)00084-X.

Krijgsman, W., F. J. Hilgen, I. Raffi, F. J. Sierro, and D. S. Wilson (1999b), Chronology, causes and progression of the Messinian salinity crisis, Nature, 400, 652-655, doi:10.1038/23231.

Krijgsman, W., S. Gaboardi, F. J. Hilgen, S. Iaccarino, E. de Kaenel, and E. van der Laan (2004), Revised astrochronology for the Ain el Beida section (Atlantic Morocco): No glacio-eustatic control for the onset of the Messinian Salinity Crisis, Stratigraphy, 1, 87-101.

Lacombe, H., P. Tchernia, and L. Gamberoni (1985), Variable bottom water in the western Mediterranean basin, Prog. Oceanogr., 14, 319-338, doi:10.1016/0079-6611(85)90015-1.

Larrasoaña, J. C., J. A. González-Delgado, J. Civis, F. J. Sierro, G. AlonsoGavilán, and J. Pais (2008), Magnetobiostratigraphic dating and environmental magnetism of Late Neogene marine sediments recovered at the Huelva-1 and Montemayor-1 boreholes (lower Guadalquivir basin, Spain), Geo-Temas, 10, 1175-1178

Llave, E., J. Schönfeld, F. J. Hernández-Molina, T. Mulder, L. Somoza V. Díaz del Río, and I. Sánchez-Almazo (2006), High-resolution stratigraphy of the Mediterranean outflow contourite system in the Gulf of
Cadiz during the late Pleistocene: The impact of Heinrich events, Mar. Geol., 227, 241-262, doi:10.1016/j.margeo.2005.11.015.

Llave, E., H. Matías, F. J. Hernández-Molina, G. Ercilla, D. A. V. Stow, and T. Medialdea (2011), Pliocene-Quaternary contourites along the northern Gulf of Cadiz margin: Sedimentary stacking pattern and regional distribution, Geo Mar. Lett., 31, 377-390, doi:10.1007/s00367-0110241-3.

Loubere, P. (1987), Changes in mid-depth North Atlantic and Mediterranean circulation during the late Pliocene-Isotopic and sedimentological evidence, Mar. Geol., 77, 15-38, doi:10.1016/0025-3227(87)90081-8.

Lourens, L. J., F. J. Hilgen, N. J. Shackleton, J. Laskar, and D. S. Wilson (2004), The Neogene Period, in A Geologic Time Scale 2004, edited by F. M. Gradstein et al., pp. 409-440, Cambridge Univ. Press, Cambridge, U. K.

Maldonado, A., and C. H. Nelson (1999), Interaction of tectonic and depositional processes that control the evolution of the Iberian Gulf of Cadiz margin, Mar. Geol., 155, 217-242, doi:10.1016/S0025-3227(98)00148-0.

Marshall, J., and F. Schott (1999), Open-ocean convection: Observations, theory, and models, Rev. Geophys., 37, 1-64, doi:10.1029/98RG02739.

Martín, J. M., J. C. Braga, and C. Betzler (2001), The Messinian Guadalhorce Corridor: The last northern, Atlantic-Mediterranean gateway, Terra Nova, 13, 418-424, doi:10.1046/j.1365-3121.2001.00376.x.

Martín, J. M., J. C. Braga, J. Aguirre, and A. Puga-Bernabéu (2009), History and evolution of the North-Betic Strait (Prebetic Zone, Betic Cordillera): A narrow, early Tortonian, tidal-dominated, AtlanticMediterranean marine passage, Sediment. Geol., 216, 80-90, doi:10.1016/ j.sedgeo.2009.01.005

MEDOC Group (1970), Observation of formation of deep water in the Mediterranean Sea, Nature, 227, 1037-1040, doi:10.1038/2271037a0.

Millot, C. (1999), Circulation in the western Mediterranean Sea, J. Mar. Syst., 20, 423-442, doi:10.1016/S0924-7963(98)00078-5.

Murphy, L. N., D. B. Kirk-Davidoff, N. Mahowald, and B. L. Otto-Bliesner (2009), A numerical study of the climate response to lowered Mediterranean Sea level during the Messinian Salinity Crisis, Palaeogeogr. Palaeoclimatol. Palaeoecol., 279, 41-59, doi:10.1016/j.palaeo.2009. 04.016

Nelson, C. H. (1990), Estimated post-Messinian sediment supply and sedimentation rates on the Ebro continental margin, Spain, Mar. Geol., 95 , 395-418, doi:10.1016/0025-3227(90)90126-5.

Nelson, C. H., J. Baraza, and A. Maldonado (1993), Mediterranean undercurrent sandy contourites, Gulf of Cádiz, Spain, Sediment. Geol., 82, 103-131, doi:10.1016/0037-0738(93)90116-M

Nisancioglu, K., M. E. Raymo, and P. H. Stone (2003), Reorganization of Miocene deep water circulation in response to the shoaling of the Central American Seaway, Paleoceanography, 18(1), 1006, doi:10.1029/ 2002PA000767.

Pérez-Asensio, J. N., J. Aguirre, G. Schmiedl, and J. Civis (2012), Messinian paleoenvironmental evolution in the lower Guadalquivir Basin (SW Spain) based on benthic foraminifera, Palaeogeogr. Palaeoclimatol. Palaeoecol., 326-328, 135-151, doi:10.1016/j.palaeo.2012.02.014.

Pinardi, N., and E. Masetti (2000), Variability of the large scale general circulation of the Mediterranean Sea from observations and modelling: A review, Palaeogeogr. Palaeoclimatol. Palaeoecol., 158, 153-173, doi:10.1016/S0031-0182(00)00048-1.

Price, J. F., and M. O’Neill-Baringer (1994), Outflows and deep water production by marginal seas, Prog. Oceanogr., 33, 161-200, doi:10.1016/ 0079-6611(94)90027-2.

Raddatz, J., A. Rüggeberg, S. Margreth, W.-C. Dullo, and IODP Expedition 307 Scientific Party (2011), Paleoenvironmental reconstruction of Challenger Mound initiation in the Porcupine Seabight, NE Atlantic, Mar. Geol., 282, 79-90, doi:10.1016/j.margeo.2010.10.019.

Rahmstorf, S. (1998), Influence of Mediterranean Outflow on climate, Eos Trans. $A G U, 79,281-282$, doi:10.1029/98EO00208.

Reid, J. L. (1979), On the contribution of the Mediterranean Sea outflow to the Norwegian-Greenland Sea, Deep Sea Res., 26, 1199-1223, doi:10.1016/0198-0149(79)90064-5.

Riaza, C., and W. Martínez del Olmo (1996), Depositional model of the Guadalquivir-Gulf of Cádiz Tertiary basin, in Tertiary Basins of Spain, edited by P. Friend and C. J. Dabrio, pp. 330-338, Cambridge Univ. Press, Cambridge, U. K., doi:10.1017/CBO9780511524851.047.

Riding, R., J. C. Braga, J. M. Martin, and I. M. Sánchez-Almazo (1998), Mediterranean Messinian salinity crisis: Constraints from a coeval marginal basin, Sorbas, SE Spain, Mar. Geol., 146, 1-20, doi:10.1016/ S0025-3227(97)00136-9.

Rogerson, M., E. J. Rohling, P. P. E. Weaver, and J. W. Murray (2005), Glacial to interglacial changes in the settling depth of the Mediterranean Outflow plume, Paleoceanography, 20, PA3007, doi:10.1029/ 2004PA001106. 
Rogerson, M., E. J. Rohling, and P. P. E. Weaver (2006), Promotion of meridional overturning by Mediterranean-derived salt during the last deglaciation, Paleoceanography, 21, PA4101, doi:10.1029/2006PA001306.

Rogerson, M., et al. (2010), Enhanced Mediterranean-Atlantic exchange during Atlantic freshening phases, Geochem. Geophys. Geosyst., 11 , Q08013, doi:10.1029/2009GC002931.

Rogerson, M., J. Schönfeld, and M. J. Leng (2011), Qualitative and quantitative approaches in palaeohydrography: A case study from core-top parameters in the Gulf of Cadiz, Mar. Geol., 280, 150-167, doi:10.1016/ j.margeo.2010.12.008.

Rogerson, M., E. J. Rohling, G. R. Bigg, and J. Ramirez (2012), Paleoceanography of the Atlantic-Mediterranean exchange: Overview and first quantitative assessment of climatic forcing, Rev. Geophys., 50, RG2003, doi:10.1029/2011RG000376.

Sanz de Galdeano, C., and J. Rodríguez-Fernández (1996), Neogene palaeogeography of the Betic Cordillera: An attempt at reconstruction, in Tertiary Basins of Spain, edited by P. Friend and C. J. Dabrio, pp. 323-329, Cambridge Univ. Press, Cambridge, U. K., doi:10.1017/ CBO9780511524851.046.

Sanz de Galdeano, C., and J. A. Vera (1992), Stratigraphic record and palaeogeographical context of the Neogene basins in the Betic Cordillera, Spain, Basin Res., 4, 21-36, doi:10.1111/j.1365-2117.1992.tb00040.x.

Schönfeld, J. (1997), The impact of the Mediterranean Outflow Water (MOW) on benthic foraminiferal assemblages and surface sediments at the southern Portuguese continental margin, Mar. Micropaleontol., 29 , 211-236, doi:10.1016/S0377-8398(96)00050-3.

Schönfeld, J., and R. Zahn (2000), Late Glacial to Holocene history of the Mediterranean Outflow. Evidence from benthic foraminiferal assemblages and stable isotopes at the Portuguese margin, Palaeogeogr. Palaeoclimatol. Palaeoecol., 159, 85-111, doi:10.1016/S0031-0182(00) 00035-3.

Schulz, M., and M. Mudelsee (2002), REDFIT: Estimating red-noise spectra directly from unevenly spaced paleoclimatic time series, Comput. Geosci., 28, 421-426, doi:10.1016/S0098-3004(01)00044-9.

Shackleton, N. J., M. A. Hall, and D. Pate (1995), Pliocene stable isotope stratigraphy of site 846, Proc. Ocean Drill. Program, Sci. Results, 138, 337-355, doi:10.2973/odp.proc.sr.138.117.1995.

Sierro, F. J., J. A. Flores, J. Civis, J. A. González-Delgado, and G. Francés (1993), Late Miocene globorotaliid event-stratigraphy and biogeography in the NE-Atlantic and Mediterranean, Mar. Micropaleontol., 21 , 143-167, doi:10.1016/0377-8398(93)90013-N.

Sierro, F. J., J. A. González-Delgado, C. J. Dabrio, J. A. Flores, and J. Civis (1996), Late Neogene depositional sequences in the foreland basin of Guadalquivir (SW Spain), in Tertiary Basins of Spain, edited by P. Friend and C. J. Dabrio, pp. 339-345, Cambridge Univ. Press, Cambridge, U. K., doi:10.1017/CBO9780511524851.048.

Sierro, F. J., et al. (2005), Impact of iceberg melting on Mediterranean thermohaline circulation during Heinrich events, Paleoceanography, 20, PA2019, doi:10.1029/2004PA001051.
Stumpf, R., M. Frank, J. Schönfeld, and B. A. Haley (2010), Late Quaternary variability of Mediterranean Outflow Water from radiogenic $\mathrm{Nd}$ and $\mathrm{Pb}$ isotopes, Quat. Sci. Rev., 29, 2462-2472, doi:10.1016/j. quascirev.2010.06.021

Thiede, J., A. Winkler, T. Wolf-Welling, O. Eldholm, A. M. Myhre, K.-H. Baumann, R. Henrich, and R. Stein (1998), Late Cenozoic history of the polar North Atlantic: Results from ocean drilling, Quat. Sci. Rev., 17, 185-208, doi:10.1016/S0277-3791(97)00076-0.

Toucanne, S., T. Mulder, J. Schönfeld, V. Hanquiez, E. Gonthier, J. Duprat, M. Cremer, and S. Zaragosi (2007), Contourites of the Gulf of Cadiz: A high-resolution record of the paleocirculation of the Mediterranean Outflow Water during the last 50,000 years, Palaeogeogr. Palaeoclimatol. Palaeoecol., 246, 354-366, doi:10.1016/j.palaeo.2006.10.007.

van der Laan, E., S. Gaboardi, F. J. Hilgen, and L. J. Lourens (2005), Regional climate and glacial control on high-resolution oxygen isotope records from Ain El Beida (latest Miocene, northwest Morocco): A cyclostratigraphic analysis in the depth and time domain, Paleoceanography, 20, PA1001, doi:10.1029/2003PA000995.

van der Laan, E., F. J. Hilgen, L. J. Lourens, E. de Kaenel, S. Gaboardi, and S. Iaccarino (2012), Astronomical forcing of Northwest African climate and glacial history during the late Messinian (6.5-5.5 Ma), Palaeogeogr. Palaeoclimatol. Palaeoecol., 313-314, 107-126, doi:10.1016/j. palaeo.2011.10.013.

Van Rooij, D., et al. (2010), The Le Danois Contourite Depositional System: Interactions between the Mediterranean Outflow Water and the upper Cantabrian slope (North Iberian margin), Mar. Geol., 274, 1-20, doi:10.1016/j.margeo.2010.03.001.

Vera, J. A. (2000), El Terciario de la Cordillera Bética: Estado actual de conocimientos, Rev. Soc. Geol. Esp., 13, 345-373.

Vergnaud-Grazzini, C. (1983), Reconstruction of Mediterranean Late Cenozoic hydrography by means of carbon isotope analyses, Utrecht Micropaleontol. Bull., 30, 25-47.

Vidal, L., T. Bickert, G. Wefer, and U. Röhl (2002), Late Miocene stable isotope stratigraphy of SE Atlantic ODP Site 1085: Relation to Messinian events, Mar. Geol., 180, 71-85, doi:10.1016/S0025-3227(01)00206-7.

Voelker, A. H. L., S. M. Lebreiro, J. Schönfeld, I. Cacho, H. Erlenkeuser, and F. Abrantes (2006), Mediterranean outflow strengthening during northern hemisphere coolings: A salt source for the glacial Atlantic?, Earth Planet. Sci. Lett., 245, 39-55, doi:10.1016/j.epsl.2006.03.014.

Wüst, G. (1961), On the vertical circulation of the Mediterranean Sea J. Geophys. Res., 66, 3261-3271, doi:10.1029/JZ066i010p03261.

Zachos, J. C., M. Pagani, L. Sloan, E. Thomas, and K. Billups (2001), Trends, Rhythms, and Aberrations in Global Climate $65 \mathrm{Ma}$ to Present, Science, 292, 686-693, doi:10.1126/science.1059412.

Zhang, J., and D. B. Scott (1996), Integrated stratigraphy and paleoceanography of the Messinian (latest Miocene) across the North Atlantic Ocean, Mar. Micropaleontol., 29, 1-36, doi:10.1016/0377-8398(96) 00010-2. 